\title{
MENINGKATKAN KUALITAS PENDIDIKAN NASIONAL MELALUI SUPERVISI PENDIDIKAN DALAM MENCAPAI TUJUAN PENDIDIKAN NASIONAL
}

\author{
INTAN PUSPITA DEWI \\ Email: intanpuspita1904@gmail.com
}

\begin{abstract}
ABSTRAK
Kualitas pendidikan di Indonesia dapat dikategorikan rendah dan jauh ketinggalan dibandingkan dengan negara -negara lain.Oleh karena itu,pendidikan di Indonesia harus terus diperbaharui dan ditingkatkan kualitasnya.Guru merupakan komponen pendidikan yang sangat penting dalam mewujudkan tujuan pendidikan nasional. Salah satu cara untuk meningktakan kualiatas pendidikan adalah dengan meningkatkan kualitas kompetensi guru.Untuk menjadi seorang guru yang profesional dalam menjalankan tugasnya merupakan suatu hal yang tidak mudah, untuk itu guru perlu disupervisi untuk mengantarkan mereka memasuki suasana kerja yang selalu berubah sesuai perkembangan zaman.Melalui teknik supervisi ini profesionalitas seorang guru dapat ditingkatkan sehingga dapat menghasilkan prestasi belajar siswa yang tinggi,dan tujuan dari pendidikan dapat tercapai seutuhnya.
\end{abstract}

Kata Kunci : Pendidikan,supervisi pendidikan,dan profesi pendidik.

\section{LATAR BELAKANG}

Pendidikan nasional Indonesia, saat ini berada dalam situasi "kritis" baik dilihat dari sudut internal kepentingan pembangunan bangsa, maupun secara eksternal dalam kaitan dengan kompetisi antar bangsa. Fakta menunjukkan bahwa, kualitas pendidikan nasional masih rendah dan jauh ketinggalan dibandingkan dengan negara-negara lain.

Berdasarkan Survey United Nations Educational, Scientific and Cultural Organization (UNESCO), terhadap kualitas pendidikan di Negara-negara berkembang di Asia Pacific, Indonesia menempati peringkat 10 dari 14 negara. Sedangkan untuk kualitas para guru, kulitasnya berada pada level 14 dari 14 negara berkembang.

Kriten (Kriten, Wacana, \& Pendidik, n.d.) mengemukakan Guru merupakan komponen pendidikan yang sangat penting dalam mewujudkan tujuan pendidikan nasional. Ada dua hal penting yang melekat pada seorang guru yaitu sebagai tenaga pengajar dan sebagai tenaga pendidik. Dalam Undang Undang nomor 14 Tahun 2005 tentang Guru dan Dosen pada pasal 1 butir 1 menjelaskan bahwa guru adalah pendidik profesional dengan tugas utama mendidik, mengajar, membimbing, mengarahkan, melatih, menilai, dan mengevaluasi peserta didik pada pendidikan anak usia dini jalur pendidikan formal, pendidikan dasar, dan pendidikan menengah. Makna guru yang dijelaskan dalam UndangUndang tersebut adalah guru sebagai tenaga pendidik yang profesional, dengan tugas-tugas utamanya adalah mendidik, mengajar, membimbing, mengarahkan, melatih, menilai dan mengevaluasi.

Untuk menjadi seorang guru profesional yang melaksanakan tugasnya sebagai pendidik yang baik tidaklah mudah, karena sasaran dari apa yang dilakukan oleh seorang guru adalah bukan saja sekedar seseorang itu mengetahui akan tetapi juga harus memahami apa yang ia ketahui dan selanjutnya secara sadar ia mampu berbuat dan dapat bertanggung 
jawab atas apa yang telah ia lakukan itu baik terhadap dirinya, masyarakat, bangsa dan negara, bahkan lebih jauh lagi ia mampu mempertanggung jawabkan semuanya kepada Tuhan.

Dari sudut pandang manajemen SDM guru, guru masih berada dalam pengelolaan yang lebih bersifat birokratis-administratif yang kurang berlandaskan paradigma pendidikan (antara lain manajemen pemerintahan, kekuasaan, politik, dsb.). Dari aspek unsur dan prosesnya, masih dirasakan terdapat kekurang-terpaduan antara sistem pendidikan, rekrutmen, pengangkatan, penempatan, supervisi, dan pembinaan guru. Masih dirasakan belum terdapat keseimbangan dan kesinambungan antara kebutuhan dan pengadaan guru. Rerkrutmen dan pengangkatan guru masih selalu diliputi berbagai masalah dan kendala terutama dilihat dari aspek kebutuhan kuantitas, kualitas, dan distribusi. Pelaksanaan otonomi daerah yang "kebablasan" cenderung membuat manajemen guru menjadi makin semrawut. Pembinaan dan supervisi dalam jabatan guru belum mendukung terwujudnya pengembangan pribadi dan profesi guru secara proporsional.

Dengan demikian guru sangat perlu untuk disupervisi untuk mengantar mereka memasuki suasana kerja yang selalu berubah dan diperbarui. Dengan memperoleh supervisi, guru-guru tersebut dapat menyesuaikan diri dengan situasi barunya. Semua situasi tersebut di atas memerlukan adanya pelaksanaan program supervisi pendidikan yang mantap dan terarah.

Berdasarkan uraian diatas permasalahan dalam tulisan ini adalah(1)Apa saja faktor yang menyebabkan rendahnya kualitas pendidikan di Indonesia? (2)Bagaimana peran supervisi pendidikan dalam meningkatkan kualitas pendidikan nasional agar tujuan dari pendidikan dapat tercapai?.Tujuan tulisan ini adalah(1)untuk mengetahui faktor-faktor yang menyebabkan rendahnya kualitas pendidikan di Indonesia. (2) Untuk mengetahui bagaimana peran supervisi pendidikan dalam meningkatkan kualitas pendidikan nasional agar tujuan dari pendidikan dapat tercapai.

\section{PEMBAHASAN}

\section{Faktor yang mempengaruhi kualitas pendidikan di Indonesia}

Banyak permasalahan yang dihadapai bangsa indonesia dalam dunia pendidikan yang menyebabkan rendahnya kualitas pendidikan nasional. Beberapa faktor yang menyebabkan rendahnya kualitas pendidikan nasional yaitu:

1.Rendahnya Kualitas Sarana Fisik

Tidak dapat dipungkiri lagi bahwa kualitas sarana pendidikan di Indonesia masih rendah.Karena masih banyak kita temui sekolah yang masih kekuranga sarana baik berupa gedung sekolah, meja dan kursi, perpustakaan dan laboratorium sekolah.

\section{Rendahnya Kualitas Guru}

Dilihat secara kuantitas jumlah guru di Indonesia cukup memadai,tetapi secara kualitas mutu guru di Indonesia masih rendah. Berdasarkan pasal 39 UU No 20 tahun 2003 tugas seoarang guru adalah merencanakan pembelajaran,melaksanakan pembelajaran,menilai hasil pembelajaran,melakukan bimbingan,melakukan pelatihan,melakukan penelitian,dan melakukan pengabdian masyarakat.Tetapi kebanyakan guru belum memilki profesinalisme yang memadai untuk menjalankan tugasnya. 


\section{Rendahnya Prestasi Siswa}

Menurut Trends in Mathematic and Science Study (TIMSS) 2003 (2004), siswa Indonesia hanya berada di ranking ke-35 dari 44 negara dalam hal prestasi matematika dan di ranking ke-37 dari 44 negara dalam hal prestasi sains. Dalam hal ini prestasi siswa kita jauh di bawah siswa Malaysia dan Singapura sebagai negara tetangga yang terdekat. Rendahnya prestasi siswa,juga disebabkan oleh rendahnya kualitas/profesionalitas seoarng guru dalam mengajar.

\section{Mahalnya Biaya Pendidikan}

Tidak dapat dipungkiri lagi bahwa mahalnya biaya yang harus dikeluarakan untuk mengenyam bangku pendidikan,membuat banyak orang tidak memilki pilihan lain kecuali tidak bersekolah.

\section{Peran supervisi pendidikan dalam meningkatkan kualitas pendidikan nasional}

Dari berbagai macam permasalahan yang dihadapi dalam dunia pendidikan,guru memilki peran yang sangat penting dalam menentukan bagaimana kualitas pendidikan indonesia kedepanya. Guru harus memiliki kemampuan untuk mengikuti perkembangan zaman,karena proses pendidikan akan terus diperbahrui sesuai dengan perkembangan zaman.

Salah satu alternatif penyelesaian dalam permasalah tersebut yaitu dengan adanya teknik supervisi pendidikan yang tujuannya untuk meningkatkan profesionalisme seorang guru sebagai seorang pendidik dalam meningkatkan kualitas pendidikan agar tercapainya tujuan pendidikan.

Supervisi pendidikan dapat diartikan sebagai berikut :

\section{- Arti morfologis}

Supervisi berasal dari bahasa inggris " supervision" yang tersdiri dari dua perkataan "suoer" dan "vision".super berarti atas atau, sedangkan vision berarti melihat atau meninjau .

\section{- Arti semantic}

Supervisi pendidikan adalah pembinaan yang berupa bimbingan atau tuntunan kearah perbaikan situasi pendidikan pada umumnya dan peningkatan pada mutu mengajar dan belajar pada khususnya. Tujuan utama supervisi adalah memperbaiki pengajaran. Sedangkan Tujuan umum Supervisi adalah memberikan bantuan teknis dan bimbingan kepada guru dan staf agar personil tersebut mampu meningkatkan kualitas kinerjanya, dalam melaksanakan tugas dan melaksanakan proses belajar mengajar.

Sabandi(Sabandi, 2013) mengemukakan secara umum dikenal,supervisi dilakukan oleh supervisor dengan melakukan kunjungan kelas.Supervisor memeriksa dan mengomentari persiapan mengajar yang dibuat oleh guru dan kemudian melakukan observasi dan memberi komentar terhadap guru tentang hal-hal yang perlu ditingkatkan. Pendekatan supervisi yang demikian tidak selalu dilakukan secara utuh terkadang hanya sampai tahap memeriksa persiapan mengajar yang dibuat oleh guru.Seharusnya supervisi dilakukan dalam rangka menjamin pembelajaran yang berkualitas. Artinya, bahwa keberhasilan pelaksanaan supervisi diukur dari peningkatan prestasi belajar siswa. 
Dengan memperoleh supervisi, guru-guru tersebut dapat menyesuaikan diri dengan situasi barunya.Mereka dapat menyesuaikan pembelajaran dengan perkembangan ilmu pengetahuan dan teknologi sesuai perkembangan zaman. Semua situasi tersebut di atas memerlukan adanya pelaksanaan program supervisi pendidikan yang mantap dan terarah. Untuk melaksanakan program supervisi pendidikan yang mantap perlu adanya evaluasi yang baik yaitu dengan berpegang teguh kepada prinsip-prinsip obyektif, kooperatif, integral, dan kontinyu.

Dengan adanya supervisi,nantinya diharapkan dapat meningkatkan kualitas/ profesionalitas seorang guru, yang akan berdampak pada peningkatan prestasi belajar siswa. Sehingga kualitas pendidikan Indonesia meningkat menjadi lebih baik.Dan tujuaan pendidikan dapat tercapai seutuhnya.

\section{KESIMPULAN DAN SARAN}

\section{Kesimpulan}

Banyak permasalah yang dihadapai bangsa indonesia yang menyebabkan rendahnya kualitas dan mutu pendidikan. Dibanding dengan negara-negara lain Indonesia jauh tertinggal. Penyebabnya adalah rendahnya kualitas guru, rendahnya sarana fisik, mahalnya biaya pendidikan, rendahnya prestasi siswa.

Guru mengambil peran penting dalam menentukan bagaimana kualitas pendidikan.Untuk itu guru harus memiliki profesionalisme yang tinggi sebagai pendidik dan juga dapat mengikuti pendidikan sesuai perkembangan zaman. Dengan adanya supervisi pendidikan dapat membantu meningkatkan profesionalisme guru sehingga kualitas pendidikan akan meningkat dan tujuan pendidikan dapat tercapai.

\section{Saran}

Seorang guru harus profesional sebagai seorang pendidik agar kualitas an tujuan pendidikan dapat tercapai dengan baik.

\section{REFERENSI}

Kriten, U., Wacana, S., \& Pendidik, P. (n.d.). Supervisi Pada Zaman Sekarang dan Masa Depan.

Sabandi, A. (2013). SUPERVISI PENDIDIKAN UNTUK PENGEMBANGAN

PROFESIONALITAS GURU BERKELANJUTAN. Pedagogi ,Jurnal Ilmiah Ilmu

Pendidikan, 13(2), 1-9. Retrieved from

http://ejournal.unp.ac.id/index.php/pedagogi/article/view/4275/3345 